\title{
Grønn stær etter lynnedslag
}

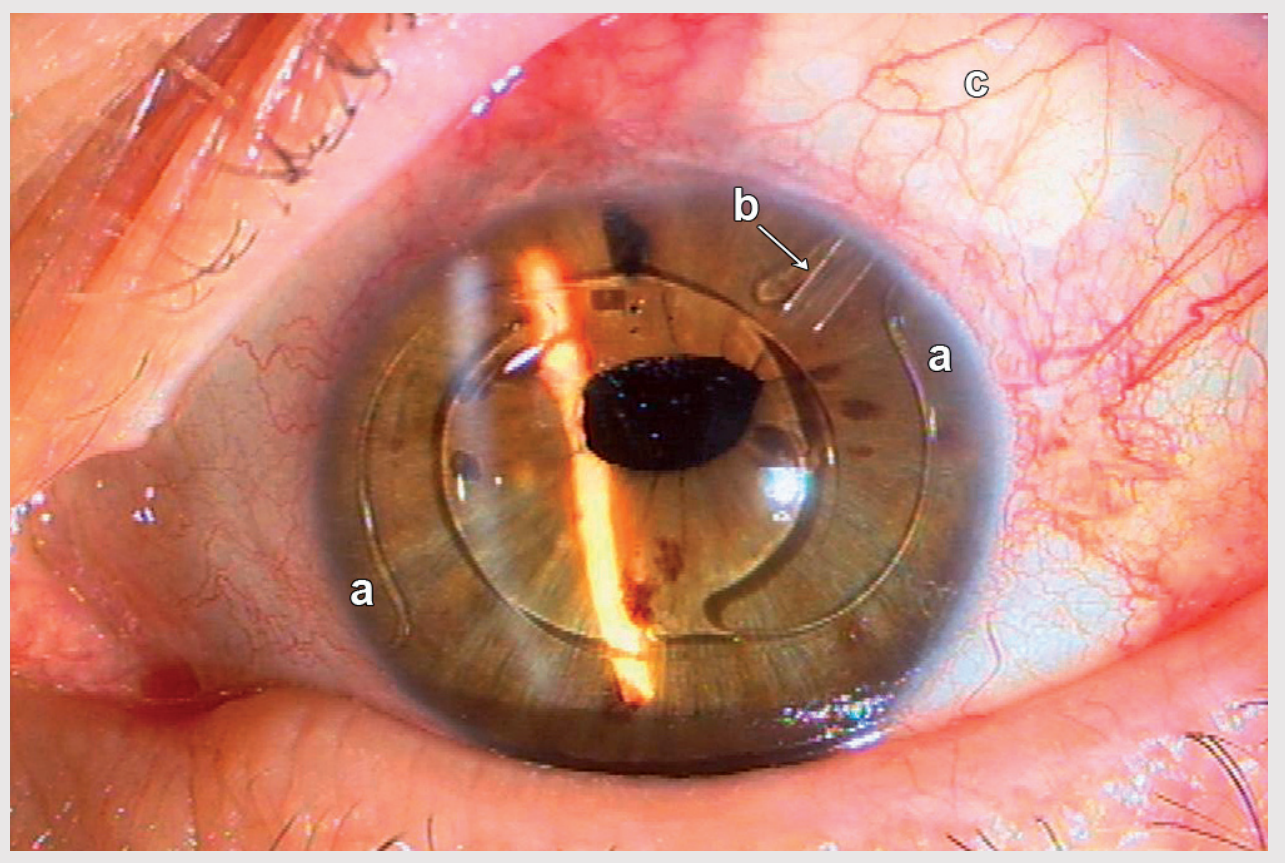

En kvinne på 58 år ble truffet av lynet fem år gammel og pådro seg brannskader og katarakt (cataracta electrica). Ett og et halvt år etter lynnedslaget ble hennes uklare biologiske linser fjernet med linsekapslene. På grunn av afaki måtte hun bruke stærbriller med styrke +15 dioptrier.

Da hun var i slutten av 30-årene, fikk hun operert inn kunstige linser i øyets fremre kammer og kunne slutte å bruke stærbrillene. Slike kunstige linser holdes på plass av to S-formede bein som ligger i kammervinkelen, hvor øyevæsken dreneres ut (a). Forkammerlinser gir økt risiko for sekundært glaukom og hornhinneproblemer. I dag bruker man nærmest bare bakkammerlinser ved kataraktoperasjoner.

Kvinnen utviklet glaukom og brukte trykknedsettende øyedråper i flere år. Grunnet økende glaukomskade ble det implantert en ventil av silikonmateriale i begge øynene, og hun kunne slutte med trykksenkende dråper.
Selve ventillegemet, som måler $16 \times 13 \times$ $1,9 \mathrm{~mm}$, ligger under conjunctiva oppad temporalt på bulbus, og slangen fra ventilen (b) stikker inn i forkammeret. Denne slangen forløper under conjunctiva og leder øyevæske til ventilen. Slangen er i tillegg dekket av en bit av sclera (c) fra en donor - for å hindre at materialet eksponeres mot overflaten over tid.

\section{Jon Klokk Slettedal}

Øyeavdelingen

Oslo universitetssykehus, Ullevål og

Det medisinske fakultet, Universitetet i Oslo

Turid Skei Tønset

Øyeavdelingen

Oslo universitetssykehus, Ullevål

\section{Britt Gundersen}

Hamar øyelegesenter

Pasienten har gitt samtykke til at artikkelen blir publisert.
Bilde av ventilen finnes kun i Tidsskriftets nettutgave.

Jon Klokk Slettedal (f. 1973) er overlege ved Øyeavdelingen, Oslo universitetssykehus, Ullevål og førsteamanuensis ved Det medisinske fakultet, Universitetet i Oslo. Ingen oppgitte interessekonflikter.

Turid Skei Tønset (f. 1961) er overlege ved Øyeavdelingen, Oslo universitetssykehus, Ullevål. Ingen oppgitte interessekonflikter.

Britt Gundersen (f. 1959) er praktiserende spesialist ved Hamar øyelegesenter. Ingen oppgitte interessekonflikter.

Mottatt 1.9. 2011, første revisjon innsendt 13.9. 2011, godkjent 15.9. 2011. Medisinsk redaktør Jon Amund Kyte. 